\begin{tabular}{|l|l|}
\hline $\begin{array}{l}\text { 2. To: (Receiving Organization) } \\
\text { DISTRIBUTION }\end{array}$ & $\begin{array}{l}\text { 3. From: (Originating Organization) } \\
\text { INTERIM STABILIZATION }\end{array}$ \\
\hline $\begin{array}{l}\text { 5. Proj./Prog./Dept./Div.: } \\
\text { INTERIM STABILIZATION }\end{array}$ & $\begin{array}{l}\text { 6. Design Authority/Design Agent/Cog. Engr.: } \\
\text { W. E. ZUROFF }\end{array}$ \\
\hline $\begin{array}{l}\text { 8. Originator Remarks: } \\
\text { ATTACHED IS AN ACCEPTANCE TEST PLAN (ATP) FOR THE NEW PUMPING } \\
\text { INSTRUMENTATION AND CONTROL (PIC) SKIDS BEING FABRICATED BY SITE } \\
\text { FABRICATION SERVICES. }\end{array}$
\end{tabular}

11. Receiver Remarks: NONE

11A. Design Baseline Document? $O$ Yes $O$ No
4. Related EDT No:
$\mathrm{N} / \mathrm{A}$
7. Purchase Order No.
$\mathrm{N} / \mathrm{A}$
9. Equip./Component No.:

$\mathrm{N} / \mathrm{A}$

10. System/Bidg./Facility:

241-U

12. Major Assm. Dwg. No.:

$\mathrm{N} / \mathrm{A}$

13. Permit/Permit Application No.:

N/A

14. Required Response Date: $11 / 05 / 99$

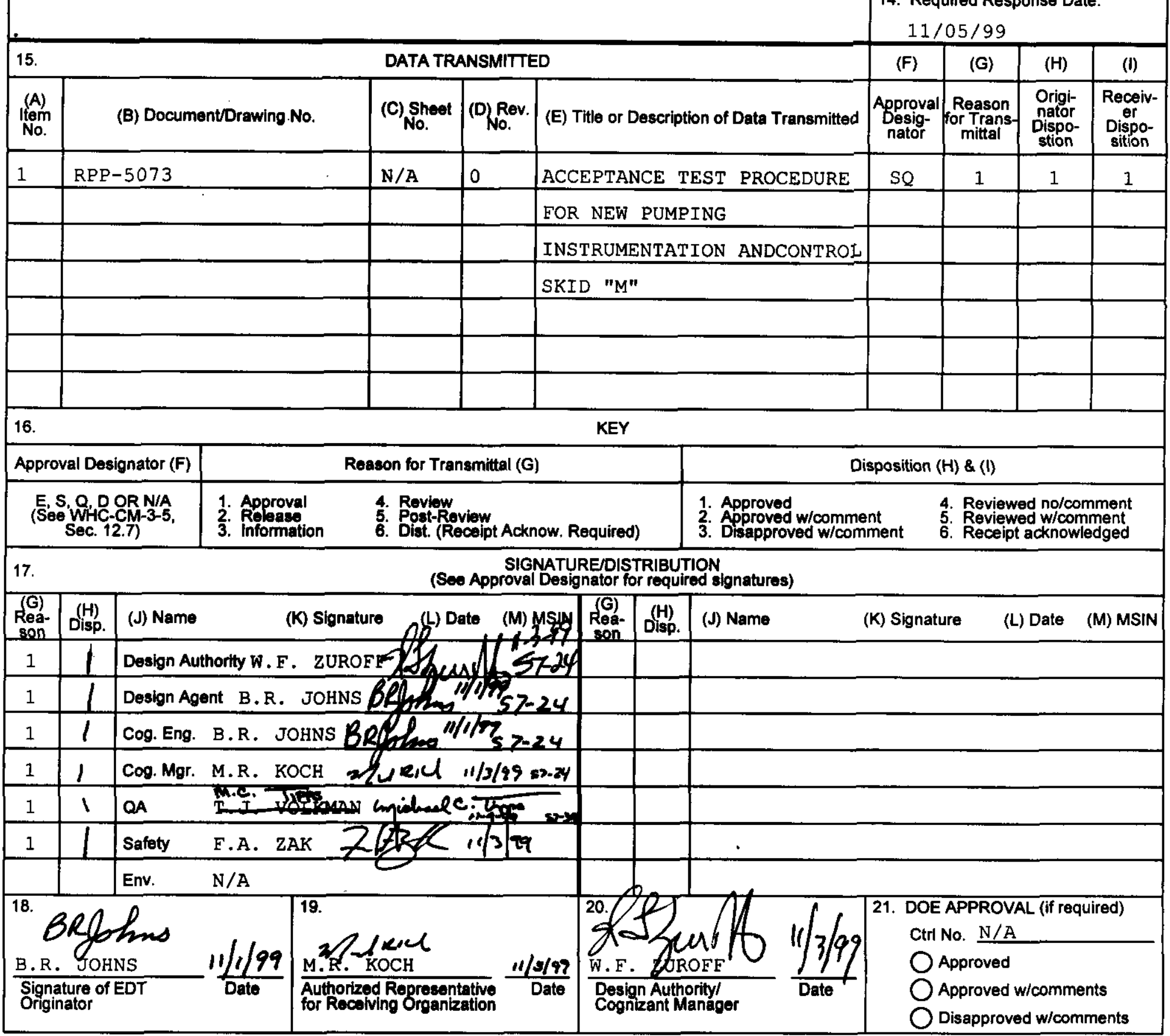




\title{
ACCEPTANCE TEST PROCEDURE FOR NEW PUMPING AND INSTRUMENTATION CONTROL SKID "M"
}

M. R. $\mathrm{XOCH}$

LOCKHEED MARTIN HANFORD CORPORATION

Richland, WA 99352

U.S. Department of Energy Contract DE-AC06-96RL13200

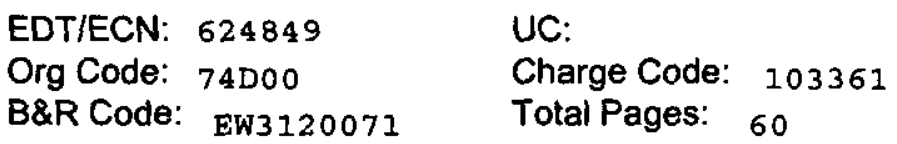

Key Words: PICS, SALT WELL, SKID, INTERIM STABILIZATION, TESTING

\begin{abstract}
:
This Acceptance Test Procedure (ATP) provides for the inspection and testing of the new Pumping and Instrumentation Control (PIC) skid designed as "M". The ATP will be performed after the construction of the PIC skid in the shop.
\end{abstract}

TRADEMARK DISCLAIMER. Reference herein to any specific commercial product, process, or service by trade name, trademark, manufacturer, or othenwise, does not necessarily constitute or imply its endorsernent, recommendation, or favoring by the United States Government or any agency thereof or its contractors or subcontractors.

Printed in the United States of America. To obtain copies of this document, contact: Document Control Services, P.O. Box 950, Mailstop H6-08, Richland WA 99352, Phone (509) 372-2420; Fax (509) 376-4989.

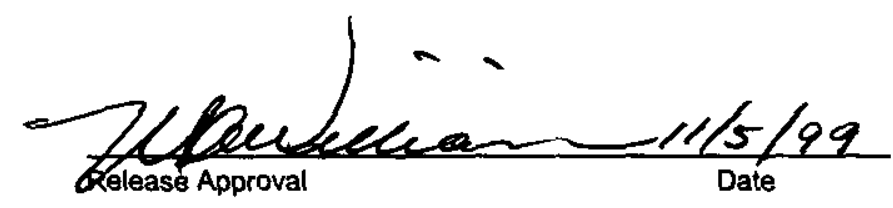

Approved For Public Release

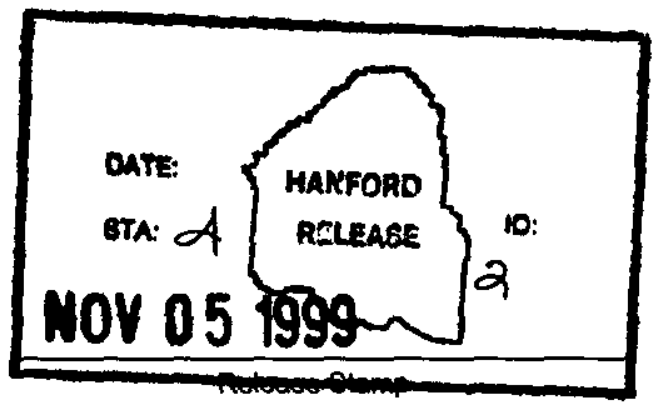




\section{TABLE OF CONTENTS}

1.0 PURPOSE

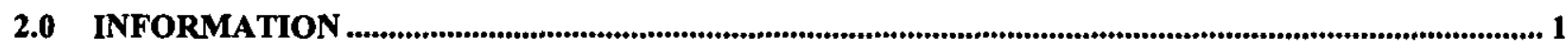

2.1 SCOPE

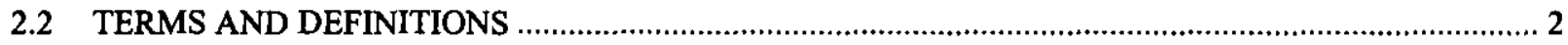

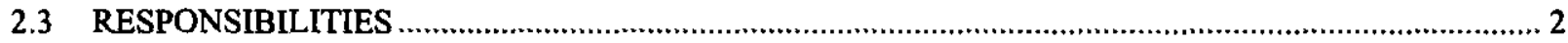

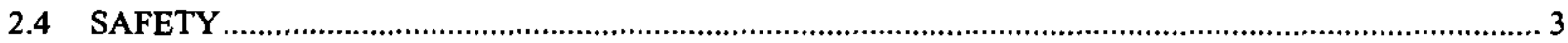

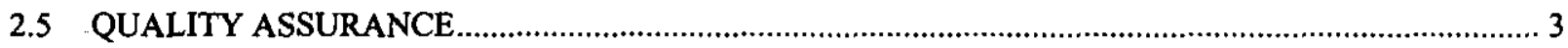

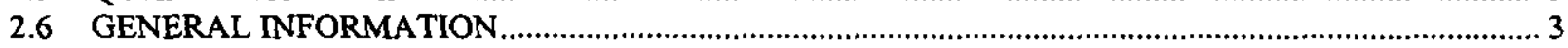

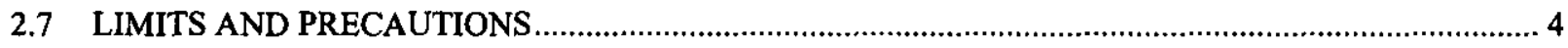

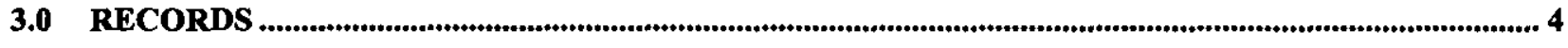

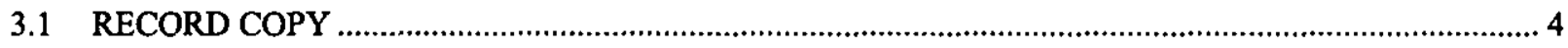

3.2 TEST RESULTS

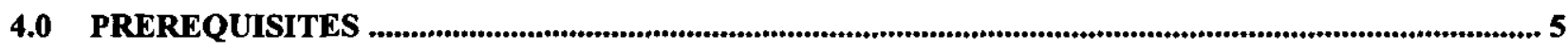

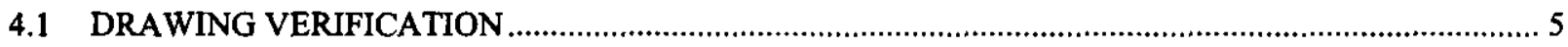

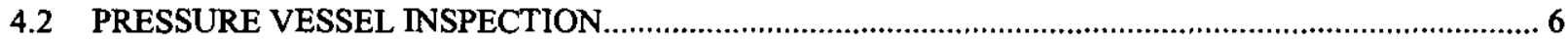

4.3 NATIONAL ELECTRICAL CODE (NEC) INSPECTION

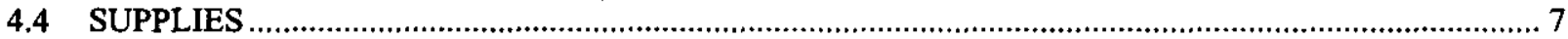

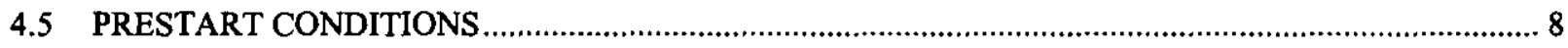

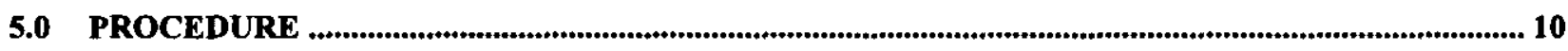

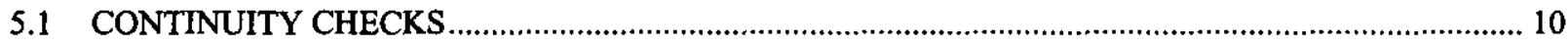

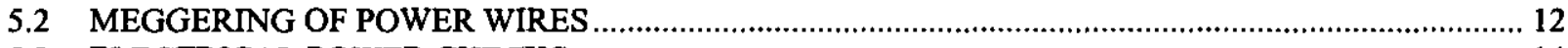

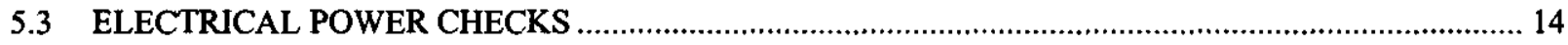

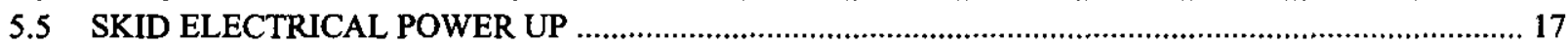

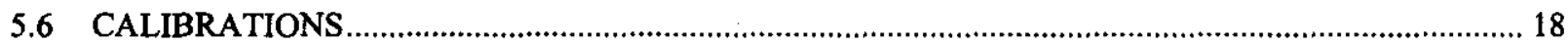

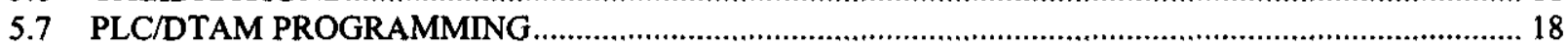

5.8 SKID ELECTRICAL AND PROCESS AIR POWER-UP …….................................................... 19

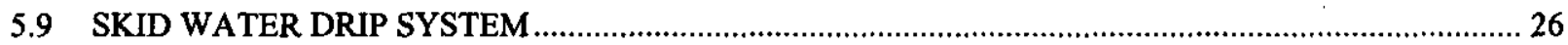

5.10 ANALOG INPUT SIGNALS TO THE PLC AND DTAM

5.11 DISCRETE SIGNAL INPUTS TO PLC AND DTAM

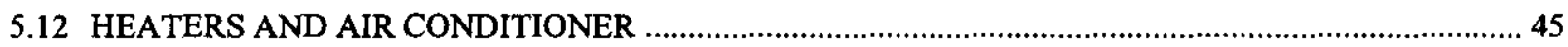

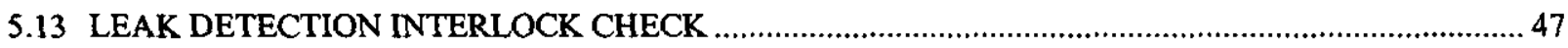

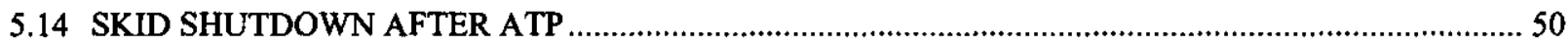

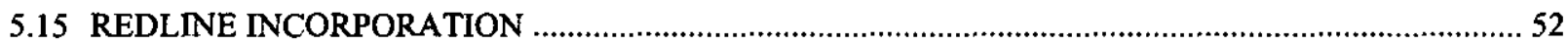


RPP-5073

REVISION 0

\section{ACCEPTANCE TEST PROCEDURE FOR NEW PUMPING AND INSTRUMENTATION CONTROL SKID "M"}

\subsection{PURPOSE}

This Acceptance Test Procedure (ATP) verifies proper construction per the design drawings and tests for proper functioning of the Pumping and Instrumentation Control (PIC) skid " $\mathrm{M}$ ". The Scope section lists the systems and functions to be checked. This ATP will be performed at the Site Fabrication Service's (SFS) shop upon completion of construction of the PIC skid.

\subsection{INFORMATION}

\subsection{SCOPE}

This Acceptance Test Procedure verifies and/or tests the following systems:

2.1.1 Drawing verification (Prerequisites)

2.1.2 Code inspections (Prerequisites)

2.1.3 Instrument calibrations

2.1.4 Continuity, megger and voltage checks

2.1.5 PLC Programming

2.1.6 Air system

2.1.7 Water system

2.1.8 PLC inputs and outputs

2.1.9 Heaters and air conditioner

2.1.10 Leak Detector Interlocks 
RPP-5073

REVISION 0

\subsection{TERMS AND DEFINITIONS}

2.2.1 DOV - Diaphragm Operated Valve

2.2.2 GPM - Gallons Per Minute

2.2.3 IA - Instrument Air

2.2.4 LDE - Leak Detector Element

2.2.5 PRV - Pressure Relief Valve

2.2.6 SGT - Specific Gravity Transmitter

2.2.7 WFT - Weight Factor Transmitter

2.2.8 LT - Level Transmitter

2.2.9 WFIE - Weight Factor Instrument Enclosure

2.2.10 PLC - Programmable Logic Controller

2.2.11 DTAM - Data Table Access Module

2.2.12 PSPT - Pump Suction Pressure Transducer

2.2.13 PDPT - Pump Discharge Pressure Transducer

2.2.14 JFPT - Jumper Flush Pressure Transducer

2.2.15 RFPT - Recirculation Flush Pressure Transducer

2.2.16 PIC - Person In Charge

\subsection{RESPONSIBILITIES}

2.3.1 LMHC Quality Assurance is responsible for:

2.3.1.1 Witnessing and signing steps as identified in Acceptance Test Procedure.

2.3.1.2 Verifying that the procedure sections were performed correctly.

2.3.2 Engineering personnel are responsible for:

2.3.2.1 Identifying the equipment needed for this procedure.

2.3.2.2 Recording equipment status and data per this procedure.

2.3.2.3 Conducting pre-job system walk down.

2.3.2.4 Recording data, exceptions and other notes as required.

2.3.2.5 Providing technical support during testing.

2.3.2.6 Providing programming support during testing.

2.3.2.7 Forcing data in Programmable Logic Controller program during testing. 
RPP-5073

REVISION 0

\subsection{SAFETY}

Warning: 120 VAC energized circuits and leads will be encountered during test when accessing PLC input/output terminals or the serial communication port. Observe appropriate electrical precautions as directed by HNF-PRO-088, Electrical Work Safety.

Warning: Cabinets on the PIC skid contain circuits energized with $480 \mathrm{vac}$ and 120vac. Comply with HNF-PRO-088, Electrical Work Safety.

\subsection{QUALITY ASSURANCE}

Ensure that the testing is performed per this procedure. The LMHC Quality Assurance Inspector shall sign and date each procedure section verifying the data obtained, and verifying that the procedure section has been performed correctly.

\subsection{GENERAL INFORMATION}

2.6.1 All data entries recorded in this procedure shall be made in black or blue ink.

2.6.2 Editorial changes required to this ATP may be made by redlining the affected section by the engineer as long as the change does not impact personnel safety or the technical aspects of this procedure. These changes shall be recorded on the ATP log sheet.

2.6.3 Unexpected results during testing shall be logged in the Acceptance Test Procedure "Exception Log" and documented on an Acceptance Test Procedure "Exception Record."

2.6.4 Technical changes to this test shall be logged as "Exceptions" and documented on the "Exception Record."

2.6.5 Do not perform any part of this procedure on faulty equipment. If faulty equipment is discovered, STOP the execution of that section of this procedure and resolve the problem OR continue with another section until the problem is repaired.

2.6.6 If the performance of this procedure is suspended for any reason, ensure the equipment is left in a safe condition per direction of the test engineer and/or PIC.

2.6.7 This procedure DOES NOT contain separate data/verification sheets. Verification of procedural steps and validity of data is recorded in this procedure next to each step as required.

2.6.8 If performance of this procedure is suspended for any reason, ensure if necessary, any Lock and Tag system requirements are met before leaving the test site. 


\section{RPP-5073 \\ REVISION 0}

2.6.9 A Job Hazard Analysis form shall be used in conjunction with the pre-job safety meeting form when any unusual hazards are identified. The pre-job meeting form shall be used to document all attendees.

2.6.10 An ATP log shall be used to record comments concerning ATP performance such as each day's testing activities.

2.6.11 The engineer or PIC may deviate from test steps if necessary to ensure safe equipment configuration during testing or suspension of testing. Configuration shall be noted so the equipment may be restored at resumption of testing.

2.6.12 Alarms may be acknowledged during testing at the direction of the test engineer or PIC if specific instructions are not given in the test steps.

2.6.13 Sections 4.2, 4.3, 5.6, 5.7 and 5.15 can be performed out of sequence in order to facilitate completion of this ATP.

2.6.14 Sections 5.10 through 5.13 can be performed out of order as directed by the engineer and/or PIC as necessary to facilitate ATP performance.

\subsection{LIMITS AND PRECAUTIONS}

NONE

\subsection{RECORDS}

\subsection{RECORD COPY}

The record copy of this procedure when completed shall be kept with the fabrication work package.

\subsection{TEST RESULTS}

A test report, RPP-5056 shall be issued with the final test results upon completion of this ATP. 
RPP-5073

REVISION 0

\subsection{PREREQUISITES}

\subsection{DRAWING VERIFICATION}

A check of the constructed skid is to be compared to either the redlined drawings or the final unreleased skid drawings. Engineering and Quality Assurance shall verify the accuracy of the essential and support drawings. Engineering shall determine a resolution for all discrepancies by either correcting the drawings or changing the equipment.

The following drawings shall be walked down for verification of proper construction of the skid:

4.1.1 Wire terminations and wiring labeling on drawings $\mathrm{H}-14-103546$, sheets 7 through 12 and H-14-103549, sheet 5.

4.1.2 Panel board arrangement on drawing H-14-103544.

4.1.3 Flow diagrams on drawings H-14-103546, sheet 5 and H-14-103551.

Drawing verification completed. (Final drawing release is not required to continue with this ATP.)

\begin{tabular}{lc}
\hline Cognizant Engineer Signature & Date
\end{tabular}

Quality Assurance Inspector Signature Date 
RPP-5073

REVISION 0

\subsection{PRESSURE VESSEL INSPECTION}

A pressure vessel inspection by a third party inspector is required for the air compressor, the air receiver tank and relief valves located in the air compressor cabinet and the water tank and relief valves in the water cabinet. The inspection is to verify that the equipment meets National Codes for pressure vessels. An outside-certified inspector will perform this inspection. (This inspection shall be completed prior to checking the air compressor and water systems.)

Pressure vessel inspection report received. (The ATP can continue before the report is received, but must be received prior to performing section 5.8.)

Report \#

Quality Assurance Inspector Signature Date

\subsection{NATIONAL ELECTRICAL CODE (NEC) INSPECTION}

4.3.1 An NEC inspection shall be performed to verify compliance to NFPA 70, latest version.

4.3.2 Areas in particular to be inspected are 480vac and 120vac wiring and grounding.

4.3.3 An NEC inspection sticker is to be placed inside the panel board door upon the NEC inspector's acceptance of the electrical portion of the skid.

The NEC inspection performed and an NEC inspection sticker placed on the panel board door. (This needs to be completed prior to the section 5.0 functional checks.)

Report \#

Quality Assurance Inspector Signature

Date 
RPP-5073

REVISION 0

\subsection{SUPPLIES}

The following supplies are required for this ATP:

Note: Test sections may commence prior to assembly of all the test equipment. Engineer and/or PIC are to ensure test equipment available prior to the start of each section.

4.4.1 Volt/ohm meter (VOM): Portable, 0-600vac.

Calibration No. Exp. Date QA

Calibration No. Exp. Date QA

4.4.2 Transmation current (milliamp) simulator or equivalent

Calibration No. Exp. Date QA

Calibration No. Exp. Date QA

4.4.3 Manometer (capable of a minimum of 5 inches water gauge to a maximum of 20 inches water gauge for this ATP) must have a read out of variable test pressure.

Calibration No. Exp. Date QA

Calibration No. Exp. Date QA

4.4.4 Megaohm meter, at least 500vac range.

Calibration No. Exp. Date QA

4.4.5 480vac, 3 phase, 30-ampere power source for PIC skid.

4.4.6 Selector switches (2 each) with at least one NO and one NC contact.

4.4.7 Proximity switches (for simulating LS-1 and LS-2), 2 each.

4.4.8 L Leak detector probes (2 each), (Not required to be green tagged.) or 2 ON/OFF switches can be used to simulate leak detectors.

4.4.9 Heat gun to warm thermocouple probes.

4.4.10 Thermocouple or thermocouple wire for simulating jumper and pump thermocouple probes.

4.4.11 Buckets or pans for water for leak detector probe test and catching water from DIP tubes and relief valve. 
RPP -5073

REVISION 0

\subsection{PRESTART CONDITIONS}

4.5 .1 Fill the water tank at least one-third to half full of water.

4.5.2___ Ensure the PIC skid is grounded in preparation for ATP testing.

4.5.3 Ensure the following PIC skid valves in the WFIE cabinet are OPEN prior to starting this ATP.

SALW-V-6035M (EQUALIZING)

SALW-V-6036M (EQUALIZING)

4.5.4 Ensure the following PIC skid valves are CLOSED prior to starting this ATP.

Air Compressor cabinet:

Water cabinet:

SALW-V-6025M

SALW-V-6026M

SALW-V-6027M

SALW-V-6034M

SALW-V-6028M

SALW-V-6043M

SALW-V-6029M

SALW-V-6030M

SALW-V-6044M

SALW-V-6046M

SALW-V-6031M

SALW-V-6032M

SALW-V-6047M

SALW-V-6037M

SALW-V-6048M

SALW-V-6049M

WFIE Cabinet:

SALW-V-6001M

SALW-V-6002M

SALW-V-6003M

SALW-V-6004M

SALW-V-6005M

SALW-V-6006M

SALW-V-6007M

SALW-V-6008M

SALW-V-6011M

SALW-V-6012M

SALW-V-6013M

SALW-V-6014M
SALW-V-6015M

SALW-V-6016M

SALW-V-6017M

SALW-V-6018M

SALW-V-6019M

SALW-V-6020M

SALW-V-6021M

SALW-V-6035M LOW

SALW-V-6035M HIGH

SALW-V-6036M LOW

SALW-V-6036M HIGH 
RPP-5073

REVISION 0

4.5.5 Ensure the following PIC skid circuit disconnects, breakers and fuses are OPEN or OFF prior to starting this ATP.

\begin{tabular}{l} 
SALW-DS-6002M \\
\hline DS-6004M SALW-DS-6005M
\end{tabular}

The following breakers are in distribution panel SALW-DP-6001M:

\begin{tabular}{c} 
Breaker "MAIN" \\
\hline Breaker 1 \\
Breaker 3 \\
Breaker 5 \\
\hline Breaker 7 \\
Breaker 9 \\
\hline Breaker 11 \\
Breaker 13
\end{tabular}

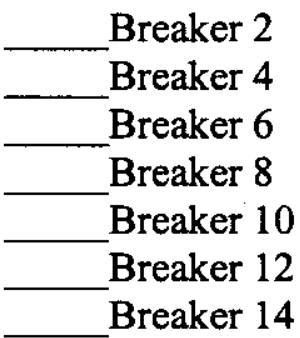

The following fuses are inside the Instrument Enclosure:

Fuses FA/FB Fuses (Leak detector/Heat trace)

4.5.6 Check for lose electrical connections at the following locations:

Terminal boards in Instrument Enclosure Motor starters and disconnect switches Terminal board in junction box inside the WFIE cabinet Terminal board in junction box for FGM outside WFIE cabinet Terminal board in heat trace splice box outside WFIE cabinet Distribution panel board 480vac power plug

4.5.7 Ensure desiccant and filters are installed in the air compressor dryer and the before and after filters prior to performing sections 5.8 and 5.9.

\subsection{8}

All personnel initialing and/or signing this procedure shall enter their signature and initials on the Procedure Performer Signature Sheet on the last page of this document. A pre-job safety meeting has been held before starting section 5.0 of this ATP. 
RPP-5073

REVISION 0

\subsection{PROCEDURE}

\subsection{CONTINUITY CHECKS}

Continuity checks shall be performed with a calibrated VOM. Perform the checks as identified below. Readings are to be less than $1 \mathrm{ohm}$. Record ohms reading on the line(s) provided. Out of tolerance readings must be corrected and rechecked prior to going to the next section. NOTE: NEC inspection must be completed prior to proceeding.

5.1.1 480vac main power plug to line side of main disconnect switch (SALWDS-6002M). Check all three phases and ground.

(RED) (YELLOW) (BLUE) (GND)

5.1.2 Load side of main disconnect switch (SALW-DS-6002M) to line side of transformer disconnect switch (SALW-DS-6003M). Check all three phases and ground.

(RED) (YELLOW or BLUE) (GND)

5.1.3 Load side of main disconnect switch (SALW-DS-6002M) to line side of jet pump motor starter (SALW-DS-6005M). Check all three phases and ground.

(RED)

(YELLOW)

(BLUE)

(GND)

5.1.4 Load side of main disconnect switch (SALW-DS-6002M) to line side of air compressor motor starter (SALW-DS-6004M). Check all three phases and ground.

(RED)

(YELLOW)

(BLUE) (GND)

5.1.5 Load side of transformer disconnect switch (SALW-DS-6003M) through primary of transformer (SALW-XFMR-6001M). Check between the twophase wires going to the transformer.

(continuity through transformer primary) 
RPP-5073

REVISION 0

5.1.6 Line side of main breaker in panel board (SALW-DP-6001M) through secondary of transformer (SALW-XFMR-6001M). Check between the two phases and between each phase and neutral going to the transformer secondary.

(Phase-A to phase-C, continuity through transformer secondary)

(Phase-A to neutral, continuity through transformer secondary)

(Phase-C to neutral, continuity through transformer secondary)

5.1.7 Load side of breakers in distribution panel (SALW-DP-6001M) to terminal point identified:

Circuit 3 to TB10 in Instrument Enclosure Circuit 5 to TB13 in Instrument Enclosure Circuit 12 to Air Conditioner/Heater receptacle in Instrument Enclosure

Circuit 6 to safe side terminal board in Intrinsic Safe Panel Circuit 1 to terminal board in FGM power junction box Circuit 11 to terminal board in FGM power junction box Circuit 13 to terminal board in FGM power junction box Circuit 14 to terminal board in FGM power junction box Circuit 2 to terminal board in FGM heat trace splice box Circuit 10 to terminal board in FGM heat trace splice box Circuit 4 to receptacle in air compressor cabinet Circuit 7 to receptacles in WFIE cabinet Circuit 8 to receptacle in Water cabinet Circuit 9 to outside receptacle below panel board

Section 5.1 completed and all recorded readings within tolerance. 
RPP-5073

REVISION 0

\subsection{MEGGERING OF POWER WIRES}

The power wires shall be checked for resistance to ground and phase to phase. A 500volt megger shall be used for this check. Minimum acceptable readings expected are greater than 1000 megaohm or infinity. Test the circuits listed below. Record readings on the lines provided. Out of tolerance readings must be corrected and rechecked before going to the next section.

5.2.1 Each of the three phases at the pins of the power plug to ground and phase to phase. (Ensure main disconnect SALW-DS-6002M is OPEN.)

A-GND ; B-GND ; C-GND ; A-B ; A-C ; B-C

5.2.2 Each of the three phases at the load side of the main disconnect switch (SALW-DS-6002M) to ground and phase to phase. (Ensure switches SALW-DS-6003M, SALW-DS-6004M and SALW-DS-6005M are OPEN.)

A-GND ; B-GND ; C-GND ; A-B ; A-C ; B-C

5.2.3 Each of the two phases on the load side of the transformer disconnect switch (SALW-DS-6003M) to ground.

A-GND ; B-GND

5.2.4 Each of the three phases on the load side of the air compressor motor to ground.

A-GND ; B-GND ; C-GND

5.2.5 Disconnect the neutral at the distribution panel from ground.

5.2.6 Each of the two phases and neutral to ground at the distribution panel. ; B-GND ; NEUTRAL-GND Reconnect the ground to the neutral at the distribution panel.

5.2.8 Disconnect the circuit 6 wire at the safe side terminal block in the intrinsic safe panel. 


\section{RPP-5073 \\ REVISION 0}

5.2.9 Megger each of the 14 circuits from the wire disconnected at the load side of the breaker to ground in the distribution panel.

NOTE: Disconnect each wire from the load side of the breaker prior to performing the megger check. Reconnect after meggering.

CKT.\#1 to GND___ ; CKT.\#2 to GND___ CKT.\#3 to GND___ CKT.\#4 to GND ; CKT.\#5 to GND

GND CKT.\#8 to GND ; CKT.\#6 to GND ; CKT.\#7 to

GND___ ; CKT.\#11 to GND ; CKT.\#9 to GND ; CKT.\#10 to ; CKT.\#12 to GND ; CKT.\#13 to Ensure the load-side wire at each breaker is connected.

5.2 .11 Reconnect the circuit-6-wire to the safe side terminal board at the Intrinsic safe panel.

Section 5.2 completed and all recorded readings are within tolerance. 
RPP-5073

REVISION 0

\subsection{ELECTRICAL POWER CHECKS}

The voltage checks are to verify proper voltages throughout the skid at specific termination points. Voltages checked are $480 \mathrm{vac}, 3$ phase; $120 \mathrm{vac}$, single phase; and $24 \mathrm{vdc}$. Out of tolerance readings must be corrected when found before going to the next step in this section.

Ensure that all electrical connections are completed. Wires lifted during the megger checks are to be reconnected.

5.3.2 Ensure all switches and breakers are open and the six fuses in the instrument cabinet are open.

5.3.3 Ensure that all the fuses are in the two safety switches (SALW-DS$\overline{6002 M}$ ) (SALW-DS-6003M) and motor starters (SALW-DS-6004M) (SALW-DS-6005M) including the control transformers are installed.

5.3.4 Connect the main power plug on the skid to a three phase, $480 \mathrm{vac}$ power source. Source to be protected by no greater than 30 amperes over current protection.

5.3.5 Turn ON the power source to the skid.

5.3.6 ENSURE 480vac $+10 \mathrm{vac} /-20 \mathrm{vac}$ on the line side of the main disconnect switch (SALW-DS-6002M). Record the voltage.

$\operatorname{vac} \mathrm{A}-\mathrm{B}$ $\operatorname{vac} \mathrm{A}-\mathrm{C}$ vac B-C

5.3.7_ Close the main disconnect switch (SALW-DS-6002M).

5.3.8_ENSURE 480vac +10 vac/-20vac on the line side of the transformer disconnect switch (SALW-DS-6003M). Record the voltage. $\operatorname{vac} \mathrm{A}-\mathrm{C}$

ENSURE 480vac $+10 \mathrm{vac} /-20 \mathrm{vac}$ on the line side of the air compressor motor starter (SALW-DS-6003M). Record the voltage. vac A-B vac A-C vac $B-C$ 
RPP-5073

REVISION 0

5.3.10_ENSURE 480vac +10vac/-20vac on the line side of the pump motor starter (SALW-DS-6005M). Record the voltage. $\operatorname{vac} \mathrm{A}-\mathrm{B}$ vac A-C vac $B-C$

5.3.11__ Remove the dead front on the panel board (SALW-DP-6001M) for access to the main breaker for a voltage measurement.

5.3.12_Close the transformer disconnect switch (SALW-DS-6003M).

5.3.13_Check for $240 \mathrm{vac}+10 /-20$ at the line side of the main breaker. Record voltage. vac

5.3.14___ Open the transformer disconnect switch (SALW-DS-6003M).

5.3.15___ Replace the dead front on the panel board (SALW-DP-6001M).

5.3.16___ Close the transformer disconnect switch (SALW-DS-6003M).

5.3.17_C Close the 100 ampere main breaker in the panel board (SALW-DP-

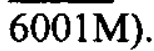


RPP-5073

REVISION 0

5.3.18_C Check voltages for circuits at the following locations. Record the voltage reading on the space provided.

\begin{tabular}{|c|c|c|c|c|}
\hline CKT \# & $\begin{array}{c}\text { CHECK VOLTAGE } \\
\text { AT }\end{array}$ & $\begin{array}{c}\text { BKR OPEN } \\
\text { VOLTAGE } \\
\text { (NEAR 0vac) }\end{array}$ & $\begin{array}{c}\text { BKR CLOSED } \\
\text { VOLTAGE } \\
(120+/-10 \mathrm{vac})\end{array}$ & $\begin{array}{c}\text { OPEN } \\
\text { BKR }\end{array}$ \\
\hline 1 & FGM J-BOX & & & \\
\hline 2 & FGM HT BOX & & & \\
\hline 3 & TB10, INSTR PNL & & & \\
\hline 4 & RCPT, AIR COMP & & & \\
\hline 5 & TB13, INSTR PNL & & & \\
\hline 6 & TB, INTRINSIC PNL & & & \\
\hline 7 & RCPT, WFIE & & & \\
\hline 8 & RCPT, WATER CAB & & & \\
\hline 9 & OUTSIDE RCPT. & & & \\
\hline 10 & FGM HT BOX & & & \\
\hline 11 & FGM J-BOX & & & \\
\hline 12 & RCPT, INSTR PNL & & & \\
\hline 13 & FGM J-BOX & & & \\
\hline 14 & FGM J-BOX & & & \\
\hline
\end{tabular}

5.3 .19 Install fuses FA, FB, FC and FD and close fuseholder.

5.3.20___ Install fuses and close heat trace/leak detector fuseholder.

5.3.21 ENSURE 120vac $+/-10 \mathrm{vac}$ at the following fuseholder load side locations.

FA ; FB ; FC ; FD

Heat trace fuse(wire CKT3H-B)

Leak Detector fuse(wire CKT3H-A)

5.3 .22 ENSURE $24 \mathrm{vdc}+/-2 \mathrm{vdc}$ at each $24 \mathrm{vdc}$ power supply.

First power supply ; second power supply

5.3.23 Open the 100 ampere main breaker in the panel board (SALW-DP$6001 \mathrm{M})$.

5.3.24___ Open the transformer disconnect switch (SALW-DS-6003M).

5.3.25___ Open the main disconnect switch (SALW-DS-6002M). 
RPP-5073

REVISION 0

Voltage checks completed satisfactorily.

Quality Assurance Inspector Signature

Date

\subsection{SKID ELECTRICAL POWER UP}

During the following sections for instrument calibration and PLC/DTAM programming, electrical power will be required to the skid. The following sequence can be used to power up and power down the skid. Record breakers closed or opened in table below. Only circuits requiring power need to be closed.

\begin{tabular}{|l|l|l|l|l|l|l|l|l|}
\hline $\begin{array}{c}\text { SWITCH OR } \\
\text { BREAKER }\end{array}$ & Close & Open & Close & Open & Close & Open & Close & Open \\
\hline SALW-DS-6002M & & & & & & & & \\
\hline SALW-DS-6003M & & & & & & & & \\
\hline CKT. \#1 & & & & & & & & \\
\hline CKT. \#2 & & & & & & & & \\
\hline CKT. \#3 & & & & & & & & \\
\hline CKT. \#4 & & & & & & & & \\
\hline CKT. \#5 & & & & & & & & \\
\hline CKT. \#6 & & & & & & & & \\
\hline CKT. \#7 & & & & & & & & \\
\hline CKT. \#8 & & & & & & & & \\
\hline CKT. \#9 & & & & & & & & \\
\hline CKT. \#10 & & & & & & & & \\
\hline CKT. \#11 & & & & & & & & \\
\hline CKT. \#12 & & & & & & & & \\
\hline CKT. \#13 & & & & & & & & \\
\hline CKT. \#14 & & & & & & & & \\
\hline
\end{tabular}


RPP-5073

REVISION 0

\subsection{CALIBRATIONS}

Instrumentation equipment on the skid requires calibration prior to the functional testing. Lockheed Martin procedures will be used for this calibration. The table below identifies the equipment requiring calibration and the procedure for performing the calibration.

\begin{tabular}{l|ll}
\hline \multicolumn{1}{c|}{ INSTRUMENT } & \multicolumn{1}{c}{ LOCATION } & \multicolumn{1}{c}{ PROCEDURE } \\
\hline SALW-PS-6004M & INSTRU. AIR CAB. & 6-PCD-508 \\
SALW-WFT-6002M & WFIE CABINET & 6-PCD-361 \\
SALW-LT-6003M & WATER CABINET & 6-PCD-361 \\
SALW-SGT-6001M & WFIE CABINET & 6-PCD-361 \\
SALW-CONV-6001M & WFIE CABINET & 6-CVT-520 \\
SALW-FQIT-6001M & INSTRUMENT CAB. & Data sheet \& Vendor Man. \\
SALW-PI-6006M & AIR COMPRS. CABINET & 6-TF-509 \\
SALW-PI-6001M & WFIE CABINET & 6-TF-509 \\
SALW-PI-6005M & WFIE CABINET & 6-TF-509 \\
SALW-PI-6002M & WFIE CABINET & 6-TF-509 \\
SALW-PI-6003M & WFIE CABINET & 6-TF-509 \\
SALW-PI-6004M & WFIE CABINET & 6-TF-509 \\
SALW-PI-6007M & AIR COMPRS. CABINET & 6-TF-509 \\
SALW-PI-6008M & WATER CABINET & 6-TF-509 \\
\hline
\end{tabular}

Calibrations completed. Work package no.

Engineer Signature

Date

\subsection{PLC/DTAM PROGRAMMING}

This section is where the programs for the PLC and DTAM will be entered. Power will be required at the instrument cabinet to power up the PLC and DTAM. Power will also be required to the GFCI receptacle for power to the laptop computer. Lockheed Martin Interim Stabilization engineering will perform the programming of the PLC and DTAM. The final software programs shall be documented as required by HNF-5034. This documentation is not part of this ATP, but will be tracked by the Acceptance for Beneficial Use (ABU) document.

PLC/DTAM programmed. 
RPP-5073

REVISION 0

\subsection{SKID ELECTRICAL AND PROCESS AIR POWER-UP}

NOTE: The Third Party Pressure Vessel inspection report must be received prior to proceeding with this section. Refer to section 4.2. Ensure desiccant in the air dryer.

5.8.1____ ENSURE the skid and remote equipment are connected before proceeding with the functional testing.

5.8.2___ ENERGIZE the Pumping and Instrumentation Control Skid by CLOSING the following DISCONNECT SWITCHES in the order found below:

\begin{tabular}{|l|c|}
\hline \multicolumn{1}{|c|}{ DISCONNECT SWITCH } & $\begin{array}{c}\text { ENERGIZED } \\
(\checkmark)\end{array}$ \\
\hline SALW-DS-6002M & \\
\hline SALW-DS-6003M & \\
\hline SALW-DS-6004M & \\
\hline SALW-DS-6005M & \\
\hline
\end{tabular}


RPP-5073

REVISION 0

5.8.3_ ENERGIZE the Pumping and Instrumentation Control Skid by CLOSING the following Circuit Breakers located in SALW-DP-6001M "SALW SKID DIST PNL" in the order found below:

\begin{tabular}{|l|l|}
\hline \multicolumn{1}{|c|}{ DISCONNECT SWITCH } & \multicolumn{1}{|c|}{$\begin{array}{c}\text { ENERGIZED } \\
(\text { ( })\end{array}$} \\
\hline "MAIN" & \\
\hline 1, FGM AND HEATER (SPARE) & \\
\hline $\begin{array}{l}\text { 3, HEAT TRACE \& LEAK DETECTION IN } \\
\text { INSTRUMENT ENCLOSURE }\end{array}$ & \\
\hline 5, INSTRUMENT CABINET & \\
\hline $\begin{array}{l}\text { 7, WEIGHT FACTOR INSTRUMENT } \\
\text { ENCLOSURE RECEPTACLES }\end{array}$ & \\
\hline 9, RECEPTACLE NEAR PNLBD & \\
\hline 11, FGM AND HEATER & \\
\hline 13, FGM SAMPLE/RETURN HEAT TRACE \\
(SPARE)
\end{tabular}


RPP-5073

REVISION 0

5.8 .4 ACKNOWLEDGE any initial skid alarms.

5.8 .5 OPEN valve SALW-V-6034M (located in the Air COMP Cabinet).

5.8.6_START air compressor SALW-CMP-6001M "SALW SKID IA COMP" by POSITIONING switch on the SALW-DS-6004M to the ON position.

5.8.7___ENSURE that Air Compressor starts and builds up pressure AND shuts off at 86 to $94 \mathrm{psig}$, as indicated by pressure gauge SALW-PI-6006M (AIR DRYER INLET PRESS). Record shut off pressure: psig

Engineer Signature Date

5.8.8 CHECK the tubing in the instrument air cabinet using a soap and water test to visually identify any air leaks. Repair as necessary. Deenergize the compressor motor and bleed off air as necessary to make repairs.

5.8.9_BLEED off air by slowly opening valve SALW-V-6043M until the compressor restarts, then close the valve and note the restart pressure.

5.8.10____ENSURE the air compressor restarts upon low pressure of 58 to 62 psig. Record pressure: psig

5.8.11 VALVE in air to the PIC Skid Water Tank by SLOWLY PERFORMING the following (Refer to H-14-103543 Sheet 1):

5.8.12 CHECK for air leaks as each remaining step in this section is performed. Make repairs as necessary. Deenergize compressor motor and bleed off air pressure if necessary to make the repairs.

5.8.13_SL_____ SLWL OPEN valve SALW-V-6025M located in the air compressor cabinet.

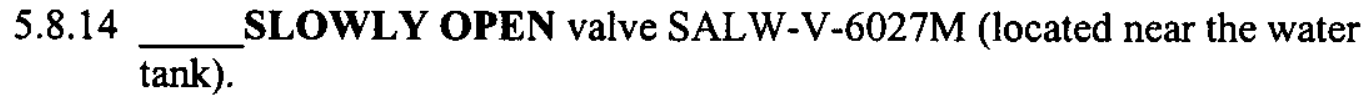

5.8.15_SLOWLY OPEN valve SALW-V-6028M (located near the water tank). 


\section{RPP-5073 \\ REVISION 0}

5.8 .16

ADJUST Pressure Regulator Valve SALW-PCV-6006M to $30 \mathrm{psi}$

( \pm 3 psig) as indicated by pressure gauge SALW-PI-6008M (WTR TK PRESS).

5.8.17 VALVE IN air to WFIE Cabinet by PERFORMING the following (Refer to H-14-103543 Sheet 1):

5.8.18_SLOWLY OPEN valve SALW-V-6026M located in the Air Compressor Cabinet.

5.8.19 SLOWLY OPEN valve SALW-V-6001M, located in the bottom of WFIE Cabinet. (NOTE: SALW-PRV-6002M may open if pressure through SALW-PCV-6001M is too high.)

ADJUST pressure control valve SALW-PCV-6001M in WFIE Cabinet to $20 \mathrm{psi}( \pm 2.5 \mathrm{psi})$ as indicated by the pressure gauge located on the face of the valve.

5.8.21 SLOWLY OPEN valve SALW-V-6004M, located in the middle of WFIE Cabinet.

5.8.22 SLOWLY OPEN valve SALW-V-6003M, located in the middle of WFIE Cabinet.

CAUTION: The next three steps cause air to flow from ports on outside of WFIE cabinet.

5.8.23 SLOWLY OPEN valve SALW-V-6005M, located in the bottom left of WFIE Cabinet.

5.8.24_SLOWLY OPEN valve SALW-V-6006M, located in the bottom left of WFIE Cabinet.

5.8.25 SLOWLY OPEN valve SALW-V-6007M, located in the bottom left of WFIE Cabinet.

5.8.26_SLOWLY OPEN valve SALW-V-6020M, located in the middle left of WFIE Cabinet.

5.8.27_SLOWLY OPEN valve SALW-V-6021M, located in the middle left of WFIE Cabinet.

5.8.28_SLOWLY OPEN valve SALW-V-6019M, located in the middle left of WFIE Cabinet. 


\section{RPP-5073 \\ REVISION 0}

5.8.29 following:

ADJUST the air flow through the diptubes by PERFORMING the

ADJUST flow to dip tubes to $1.5 \mathrm{CFH}( \pm 0.5 \mathrm{CFH})$ as indicated by SALW-FIV-6002M.

Flow Engineer Signature Date

5.8.31_ADJUST flow to dip tubes to $1.5 \mathrm{CFH}( \pm 0.5 \mathrm{CFH})$ as indicated by SALW-FIV-6003M.

Flow Engineer Signature Date

5.8.32 ADJUST flow to dip tubes to $1.5 \mathrm{CFH}( \pm 0.5 \mathrm{CFH})$ as indicated by SALW-FIV-6004M.

Flow Engineer Signature Date

5.8.33_VALVE IN SALW-WFT-6002M AND SALW-SGT-6001M by PERFORMING the following:

5.8.34 ENSURE the LOW side AND HIGH side isolation valves, located on SALW-V-6036M in cabinet WFIE Cabinet are OPEN.

5.8.35 ENSURE SALW-WFT-6002M EQUALIZING valve on valve manifold SALW-V-6036M in cabinet WFIE Cabinet is CLOSED.

5.8.36_ENSURE the LOW side AND the HIGH side isolation valves, located on SALW-V-6035M in cabinet WFIE Cabinet are OPEN.

5.8.37_ENSURE SALW-SGT-6001M equalizing valve on valve manifold SALW-V-6035M in cabinet WFIE Cabinet is CLOSED.

5.8.38 CONFIRM that a signal is present between WFIE Cabinet instruments and the Programmable Logic Controller by PERFORMING the following: 
RPP-5073

REVISION 0

5.8 .39

ENSURE Weight Factor is approximately $0.0^{\prime \prime}\left( \pm 0.5^{\prime \prime}\right)$ Water

Gauge as indicated by Data Table Access Module. If DTAM displays

$" \ll<<"$ indicating less than zero, ENSURE continuity between the

transmitter and the Programmable Logic Controller and proceed with the test.

$\overline{\text { Engineer Signature } \quad \text { Date }}$

5.8.41 ENSURE Specific Gravity is approximately 0.0" $\left( \pm 0.5^{\prime \prime}\right)$ Water Gauge as indicated by Data Table Access Module. If DTAM displays

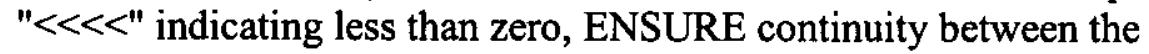
transmitter and the Programmable Logic Controller and proceed with the test.

$\overline{\text { Engineer Signature } \quad \text { Date }}$

5.8.42___ OPEN valve SALW-V-6035M Equalizing.

5.8.43_CLOSE valves SALW-V-6035M HI and LO.

5.8.44___ OPEN valve SALW-V-6036M Equalizing.

5.8.45_CLOSE valves SALW-V-6036M HI and LO.

5.8.46_CLOSE valves SALW-V-6019M, SALW-V-6021M and SALW-V$\overline{6020 \mathrm{M}}$.

5.8.47___ENSURE all air leaks repaired.

Engineer Signature

Date 
RPP-5073

REVISION 0

5.8.48 Engineer to VERIFY that section 5.8 is complete by SIGNING below.

Engineer Signature Date

5.8.49 Quality Assurance Inspector to VERIFY that section 5.8 is complete by signing below.

Quality Assurance Inspector Signature Date 
RPP-5073

REVISION 0

\subsection{SKID WATER DRIP SYSTEM}

5.9.1___ Provide a container to capture water expelled from the dip tubes and pressure relief valve SALW-PRV-6001M on the outside of the WFIE cabinet.

5.9.2_ ACTUATE the Dip Tube Drip system by SLOWLY OPENING the following valves:

\begin{tabular}{|l|c|}
\hline \multicolumn{1}{|c|}{ VALVES } & $\begin{array}{c}\text { OPEN } \\
(\checkmark)\end{array}$ \\
\hline $\begin{array}{l}\text { SALW-V-6016M } \\
\text { located in the middle of WFIE Cabinet }\end{array}$ & \\
\hline $\begin{array}{l}\text { SALW-V-6013M } \\
\text { located in the middle of WFIE Cabinet }\end{array}$ & \\
\hline $\begin{array}{l}\text { SALW-V-6008M } \\
\text { located in the middle of WFIE Cabinet }\end{array}$ & \\
\hline
\end{tabular}

\section{CAUTION}

Relief valve (SALW-PRV-6001M) will actuate and relieve pressure at 25 psig.

5.9.3 SLOWLY OPEN SALW-V-6018M WHILE CAREFULLY

ADJUSTING Pressure Regulator SALW-PCV-6005M, located in the bottom of WFIE Cabinet to 20 psig ( \pm 2 psig) as indicated by SALW-PI-6001M in the middle of WFIE Cabinet.

5.9 .4

ADJUST valve SALW-V-6014M to allow APPROXIMATELY 2

drops/second as indicated by sight glass SALW-FG-6001M $( \pm 1$ drop/second).

5.9.5_ADJUST valve SALW-V-6015M to allow APPROXIMATELY 2 drops/second as indicated by sight glass SALW-FG-6002M $( \pm 1$ drop/second). 
RPP-5073

REVISION 0

5.9 .6 VALVE OUT the dip tube drip water by SLOWLY CLOSING the following:

\begin{tabular}{|l|c|}
\hline \multicolumn{1}{|c|}{ VALVE } & $\left.\begin{array}{c}\text { CLOSED } \\
(\end{array}\right)$ \\
\hline $\begin{array}{l}\text { SALW-V-6015M } \\
\text { located in the middle of WFIE Cabinet }\end{array}$ & \\
\hline $\begin{array}{l}\text { SALW-V-6014M } \\
\text { located in the middle of WFIE Cabinet }\end{array}$ & \\
\hline $\begin{array}{l}\text { SALW-V-6008M } \\
\text { located in the middle of WFIE Cabinet }\end{array}$ & \\
\hline $\begin{array}{l}\text { SALW-V-6013M } \\
\text { located in the middle of WFIE Cabinet }\end{array}$ & \\
\hline
\end{tabular}

5.9.7_Ensure equalizing valve SALW-V-6035M is OPEN.

5.9.8___ Ensure HI and LO isolation valves on SALW-V-6035M are CLOSED.

5.9.9___Ensure equalizing valve SALW-V-6036M is OPEN.

5.9.10_Ensure HI and LO isolation valves on SALW-V-6036M are CLOSED.

5.9.11 Ensure the following valves in the order listed: SALW-V-6019M, SALW-V-6021M, SALW-V-6020M, SALW-V-6007M, SALW-V6006M, and SALW-V-6005M are CLOSED.

5.9.12_SLOWLY open valve SALW-V-6044M in the Air Compressor Cabinet.

5.9.13 ENSURE air flows from pressure regulator SALW-PCV-6007M outside Air Compressor Cabinet.

5.9.14_CLOSE valve SALW-V-6044M in the Air Compressor Cabinet.

5.9.15_SLOWLY open valve SALW-V-6048M in Air Compressor Cabinet.

5.9.16 ___ ENSURE air flows from pressure regulator SALW-PCV-6008M outside Air Compressor Cabinet. 
RPP-5073

REVISION 0

5.9 .17 CLOSE valve SALW-V-6048M in the Air Compressor Cabinet.

5.9.18_SLOWLY crack open valve SALW-V-6046M in the Air Compressor Cabinet to ENSURE air flow at the fitting for the DOV (SALW-V-6042M), then RECLOSE SALW-V-6046M.

5.9.19 SLOWLY crack open valves SALW-V-6047M and SALW-V6046M in the Air Compressor Cabinet to ENSURE air flow at the drain line.

5.9.20 CLOSE valves SALW-V-6047M and SALW-V-6046M in the Air Compressor Cabinet.

5.9.21 Engineer to VERIFY that section 5.9 is complete by SIGNING below.

Engineer Signature
Date

5.9.22 Quality Assurance Inspector to VERIFY that section 5.9 is complete by signing below.

Quality Assurance Inspector Signature Date 
RPP-5073

REVISION 0

\subsection{ANALOG INPUT SIGNALS TO THE PLC AND DTAM}

\section{Water Tank Level Transmitter}

5.10.1_ PREPARE the Water Tank Level Transmitter SALW-LT-6003M for test signals by PERFORMING the following:

5.10.2 ENSURE valve SALW-V-6029M, located in the bottom of WATER TANK ENCL, is CLOSED.

5.10.3 ENSURE valve SALW-V-6031M, located in the bottom of WATER TANK ENCL, is CLOSED.

5.10.4_CONNECT test Manometer pressure source that can output at least to 62" water gauge to the HIGH PRESSURE vent/test port of the level transmitter SALW-LT-6003M.

5.10.5_ENSURE the LOW PRESSURE vent/test port of the level transmitter SALW-LT-6003M is OPEN to atmosphere.

5.10 .6 ADJUST the test Manometer on the SALW-LT-6003M to a pressure of 31" Water Gauge ( $\pm 1 ")$.

5.10.7 _ RECORD the following:

\section{DATA TABLE ACCESS MODULE WATER TANK LEVEL (RANGE: 28.5 TO 33.5 Inches)}

NOTE - In the next step, the alarm should annunciate between 11.75" and 12.75" Water Gauge.

5.10.8_VERY SLOWLY DECREASE the Level Transmitter test Manometer pressure UNTIL the Data Table Access Module "PIC WATER LEVEL LOW" alarm (alarm 9) annunciates.

5.10.9_ACKNOWLEDGE the Water Tank Low Level alarm at the Data Table Access Module. 
RPP-5073

REVISION 0

5.10.10__ OBSERVE the Data Table Access Module AND RECORD the water tank level readings below:

\section{DATA TABLE ACCESS MODULE WATER TANK LEVEL \\ (RANGE 11.75 to 12.75 inches Water Gauge)}

5.10.11__ SLOWLY INCREASE the Level Transmitter test Manometer pressure to $15.5^{\prime \prime}$ Water Gauge.

5.10.12_ OBSERVE the Data Table Access Module AND RECORD the water tank level readings below:

\section{DATA TABLE ACCESS MODULE \\ WATER TANK LEVEL (RANGE 14.5 to 16.5 inches)}

5.10.13_ENSURE "PIC WATER" is back to "norm" on DTAM.

5.10.14__ REMOVE the test manometer from the SALW-LT-6003M high pressure vent/test port, AND RE-INSTALL vent plugs.

5.10.15_RESTORE the Water Tank Level Transmitter SALW-LT-6003M by PERFORMING the following:

5.10.16_ OPEN valve SALW-V-6029M, located in the bottom of WATER TANK ENCL.

5.10.17_ OPEN valve SALW-V-6031M, located in the bottom of WATER TANK ENCL.

5.10.18__ENSURE "WATER TANK" on DTAM shows a value in inches. 
RPP-5073

REVISION 0

\section{WEIGHT FACTOR TEST}

5.10.19_ENSURE that NO Programmable Logic Controller input signals are FORCED and that the forcing function is DISABLED.

5.10.20_CONNECT the test Manometer pressure source that can output at least a 125" water gauge to the HIGH PRESSURE dip tube on the side of the "WFIE Cabinet."

5.10.21_ENSURE SALW-V-6001M is CLOSED.

5.10.22_ENSURE SALW-V-6005M is OPEN.

5.10.23_ENSURE SALW-V-6006M is OPEN.

5.10.24___ENSURE adjustment valves on SALW-FIV-6002M, SALW-FIV6003M, SALW-FIV-6004M are CLOSED.

5.10.25_ENSURE SALW-WFT-6002M EQUALIZING valve located on SALW-V-6036M 3-Valve Manifold in cabinet WFIE Cabinet is CLOSED.

5.10.26_ENSURE the LOW side and HIGH side isolation valves, located on SALW-V-6036M 3-Valve Manifold in cabinet WFIE Cabinet are OPEN.

5.10.27___SET the test Manometer to $125^{\prime \prime}(+/-1$ ") Water Gauge.

5.10.28_OBSERVE Data Table Access Module AND RECORD the Weight Factor on the table below.

\section{DATA TABLE ACCESS MODULE WEIGHT FACTOR READING (RANGE 120 to 130 inches)}

5.10.29_BLEED off pressure from the manometer.

5.10.30_CLOSE SALW-V-6006M.

5.10.31_ OPEN SALW-WFT-6002M equalizing valve, located on SALW-V-6036M 3-Valve Manifold in cabinet WFIE Cabinet. 
RPP-5073

REVISION 0

5.10.32_CLOSE the LOW side and HIGH side isolation valves, located on SALW-V-6036M 3-Valve Manifold in cabinet WFIE Cabinet.

\section{SPECIFIC GRAVITY TEST}

5.10.33_ENSURE SALW-V-6007M is OPEN.

5.10.34_ENSURE SALW-V-6005M is OPEN.

5.10.35_ENSURE the LOW side and the HIGH side isolation valves, located on SALW-V-6035M in cabinet WFIE Cabinet are OPEN.

5.10.36_CLOSE the Specific Gravity Transmitter equalizing valve located on SALW-V-6035M in cabinet WFIE Cabinet.

5.10.37_SET the test Manometer to 5" Water Gauge ( $\pm .3 ")$.

5.10.38_ OBSERVE Data Table Access Module AND RECORD the Specific Gravity reading on the table below.

\section{DATA TABLE ACCESS MODULE \\ SPECIFIC GRAVITY READING \\ (RANGE 4.65 to 5.35 inches)}

5.10.39_BLEED off pressure from the manometer.

5.10.40_DISCONNECT the test manometer pressure source.

5.10.41_CLOSE SALW-V-6007M.

5.10.42_CLOSE SALW-V-6005M.

5.10.43_ OPEN SALW-SGT-6001M equalizing valve, located on SALW-V-6035M 3-Valve Manifold in cabinet WFIE Cabinet.

5.10.44_CLOSE the LOW side and HIGH side isolation valves, located on SALW-V-6035M 3-Valve Manifold in cabinet WFIE Cabinet. 
RPP-5073

REVISION 0

\section{FLOW METER TEST}

5.10.45_IF necessary CONNECT the brain terminal to the SALW-FQIT-6001M (SUPERNATANT FLOW XMIT), located in cabinet Instrument Cabinet.

5.10.46___ENSURE SALW-FQIT-6001M is powered and configured for simulated flow signals.

5.10 .47 SIMULATE a flow signal of $2.0 \mathrm{gpm}$ (50\% span) with the hand held calibrator, or from flowmeter face plate.

5.10.48_ENSURE the SALW-FQIT-6001M transmitter is operating properly by RECORDING the following:

\begin{tabular}{|c|c|}
\hline $\begin{array}{c}\text { DATA TABLE ACCESS MODULE } \\
\text { SUPERNATANT FLOW } \\
\text { (RANGE: 1.8 TO 2.2 GPM) }\end{array}$ & $\begin{array}{c}\text { SUPERNATANT FLOW } \\
\text { XMIT } \\
\text { SUPERNATANT FLOW } \\
\text { (RANGE: 1.8 TO 2.2 GPM) }\end{array}$ \\
\hline & \\
\hline
\end{tabular}

5.10.49_RESTORE the SALW-FQIT-6001M (SUPERNATANT FLOW TRANSMITTER) to its original configuration.

SUCTION AND DISCHARGE PRESSURE SIGNAL

5.10.50_ENSURE a current source is connected to PSPT+ and PSPT- at the intrinsic side terminal board in the Intrinsic Safe panel. Set to transmitter simulate.

5.10.51_SET the current to $4 \mathrm{~mA}$ and record the suction pressure on SALW-PI$6012 \mathrm{M}$ in the table below. Reading is to be approximately zero.

5.10 .52 SET the current source to $20 \mathrm{~mA}$ and record the suction pressure in the table below. Reading is to be approximately 100psi.

5.10.53_DISCONNECT the current source. 
RPP-5073

REVISION 0

5.10.54_ENSURE a current source is connected to PDPT+ and PDPT- at the intrinsic side terminal board in the Intrinsic Safe panel. Set to transmitter simulate.

5.10.55_SET the current to $4 \mathrm{~mA}$ and record the discharge pressures on SALWPI-6011M and on the DTAM in the table below. Readings are to be approximately zero.

5.10.56__ SET the current source to $20 \mathrm{~mA}$ and record the discharge pressures in the table below. Readings are to be approximately 300 psi.

5.10.57__ DISCONNECT the current source.

\begin{tabular}{||c|c|c|c|c|}
\hline $\begin{array}{c}\text { SALW-PI-6012M } \\
\text { JET PUMP } \\
\text { SUCTION } \\
\text { PRESSURE }\end{array}$ & & $\begin{array}{c}\text { DTAM } \\
\text { DISCHARGE } \\
\text { PRESSURE }\end{array}$ & $\begin{array}{c}\text { SALW-PI-6011M } \\
\text { JET PUMP } \\
\text { DISCHARGE } \\
\text { PRESSURE }\end{array}$ & \\
\hline & At 4mA & & & At $4 \mathrm{~mA}$ \\
\hline & At $20 \mathrm{~mA}$ & & & At $20 \mathrm{~mA}$ \\
\hline
\end{tabular}

PIT FLAMMABLE GAS MONITOR ANALOG SIGNAL TO PLC

5.10.58_ENSURE a current source is connected to terminal board TB1 in the PICS Instrument Enclosure, points FGM $0(+)$ and FGM $0(-)$.

$5.10 .59 \_$SET current source to $4 \mathrm{~mA}( \pm .25 \mathrm{~mA})$.

5.10.60__ RECORD the Data Table Access Module Flammable Gas DISPLAY on the "Pit FGM Input/Output Table" below. (Expected value to be approximately $0 \%$.)

$5.10 .61 \_$SET current source to $10 \mathrm{~mA}( \pm .25 \mathrm{~mA})$.

5.10.62__ RECORD the Data Table Access Module Flammable Gas display on the "Pit FGM Input/Output Table" below. (Expected value to be approximately $11 \%$.)

$5.10 .63 \_$SET current source to $20 \mathrm{~mA}( \pm .25 \mathrm{~mA})$. 
5.10.64__ RECORD the Data Table Access Module Flammable Gas display on the "Pit FGM Input/Output Table" below. (Expected value to be approximately $30 \%$.)

\begin{tabular}{|c|c|}
\hline \multicolumn{2}{|c|}{ Pit FGM Input/Output Table } \\
\hline $\begin{array}{c}\text { Input } \\
(\mathrm{mA})\end{array}$ & $\begin{array}{c}\text { Output (as displayed on } \\
\text { Data Table Access Module) }\end{array}$ \\
\hline 4 & \\
\hline 10 & \\
\hline 20 & \\
\hline
\end{tabular}

5.10.65_DISCONNECT the current source.

\section{DOME SPACE FLAMMABLE GAS MONITOR ANALOG SIGNAL TO PLC}

5.10.66 ENSURE a current source is connected to terminal board TB1 in the PICS Instrument Enclosure, points FGM 1(+) and FGM 1(-).

$5.10 .67 \_$SET current source to $4 \mathrm{~mA}(+/-.25 \mathrm{~mA})$.

5.10.68_RECORD the Data Table Access Module Flammable Gas DISPLAY on the "Dome Space FGM Input/Output Table" below. (Expected value to be approximately $0 \%$.)

$5.10 .69 \_$SET current source to $10 \mathrm{~mA}( \pm .25 \mathrm{~mA})$.

5.10.70__ RECORD the Data Table Access Module Flammable Gas display on the "Dome Space FGM Input/Output Table" below. (Expected value to be approximately $11 \%$.)

$5.10 .71 \_$SET current source to $20 \mathrm{~mA}( \pm .25 \mathrm{~mA})$.

5.10.72_ RECORD the Data Table Access Module Flammable Gas display on the "Dome Space FGM Input/Output Table" below. (Expected value to be approximately $30 \%$.) 
RPP-5073

REVISION 0

\begin{tabular}{|c|c|}
\hline \multicolumn{2}{|c|}{ Dome Space FGM Input/Output Table } \\
\hline $\begin{array}{c}\text { Input } \\
\text { (mA) }\end{array}$ & $\begin{array}{c}\text { Output (as displayed on } \\
\text { Data Table Access Module) }\end{array}$ \\
\hline 4 & \\
\hline 10 & \\
\hline 20 & \\
\hline
\end{tabular}

5.10.73_DISCONNECT the current source.

\section{THERMOCOUPLE INPUTS TO PLC}

5.10.74_WARM thermocouple SALW-TE-6004M, located in the Instrument Enclosure.

5.10.75__ ENSURE Data Table Access Module displays a changed temperature.

Engineer Signature Date

5.10.76_ENSURE SALW-TE-6004M temperature decreases after heat source removed.

5.10.77__WARM thermocouple SALW-TE-6003M, located in INSTRUMENT AIR ENCLOSURE.

5.10.78__ENSURE Data Table Access Module displays a changed temperature.

Engineer Signature Date

5.10.79_ENSURE SALW-TE-6003M temperature decreases after heat source removed.

5.10.80_ENSURE a thermocouple probe is connected to the intrinsic side of top thermocouple module (MTL 3081) in the Intrinsic Safe Panel. (This will simulate pump temperature.)

5.10.81_WARM the connected thermocouple probe. 
5.10.82_ENSURE Data Table Access Module displays a changed temperature.

Engineer Signature

Date

5.10.83_ENSURE the connected probe temperature decreases after heat source removed.

5.10.84_DISCONNECT the temperature probe.

5.10.85_ENSURE a thermocouple probe is connected to the second thermocouple module in the Intrinsic Safe panel. (This will simulate jumper temperature.)

5.10.86_WARM the thermocouple probe.

5.10.87_ENSURE Data Table Access Module displays a changed temperature

Engineer Signature

Date

5.10.88__ENSURE SALW-TE-6002M temperature decreases after heat source removed.

5.10.89_DISCONNECT the temperature probe.

\section{RECIRCULATION FLUSH PRESSURE SIGNAL TO PLC}

5.10.90_ENSURE a current source is connected to points RFPT+ and RFPT- at terminal board TB2 in the Instrument panel. (Set the current source to "TRANSMITTER SIMULATE."

5.10.91__ SET the current source to $4 \mathrm{~mA}$.

5.10.92_SLOWLY increase the current output until an alarm on the DTAM for High Recirc. Flush Pressure(alarm 39) occurs. (Approx. 12.5mA.)

5.10.93_ACKNOWLEDGE alarm.

5.10.94_ENSURE the pressure on the DTAM for RFPT is approximately $15 \mathrm{psi}$. 
RPP-5073

REVISION 0

5.10.95_DECREASE the current source to approximately $4 \mathrm{~mA}$.

5.10.96__ENSURE the High Recirc. Flush Pressure alarm clears on the DTAM.

5.10.97__ DISCONNECT the current source.

5.10.98__ENSURE a "RFPT SIGNAL LOSS" alarm (14) occurs.

5.10.99__ ACKNOWLEDGE the alarm.

\section{JUMPER FLUSH PRESSURE SIGNAL TO PLC}

5.10.100_ENSURE a current source is connected to points JFPT + and JFPTat the intrinsic side terminal board in the Intrinsic Safe panel. (Set the current source to "TRANSMITTER SIMULATE."

5.10.101_SET the current source to $4 \mathrm{~mA}$.

5.10.102 SLOWLY increase the current output until an alarm on the DT $\overline{A M}$ for High Flush Pressure(alarm 3) occurs and the BLUE light on the instrument panel is ON. (Approx. 12.5mA.)

5.10.103_ACKNOWLEDGE alarm.

5.10.104 ENSURE the pressure on the DTAM for JFPT is approximately $15 \mathrm{psi}$.

5.10.105_DECREASE the current source to $4 \mathrm{~mA}$.

5.10.106_ENSURE the High Flush Pressure alarm clears on the DTAM and the BLUE light turns OFF.

5.10.107_DISCONNECT the current source.

5.10.108_ENSURE a "JFPT SIGNAL LOSS" alarm (16) occurs.

5.10.109_ACKNOWLEDGE the alarm.

\section{LOW PRESSURE INTERLOCK (TRANSDUCER) INPUT}

5.10.110_ENSURE a current source is connected to points PXPT+ and PXPT- at the intrinsic side terminal board in the Intrinsic Safe panel. (Set the current source to "TRANSMITTER SIMULATE." 
RPP-5073

REVISION 0

5.10.111_ENSURE a normally closed transducer is connected across the LS-1+ and LS-1- and a normally open transducer across the LS-2+ AND LS-2- points on the intrinsic safe terminal board in the Intrinsic Safe panel.

5.10.112_ACTUATE both transducers by placing a piece of steel in front of the each transducer face.

5.10.113 ENSURE the laptop computer is connected to the PLC and on-line.

5.10.114_SET the current source to approximately $6 \mathrm{~mA}$ on transmitter simulate.

5.10.115_ENSURE the GREEN light on the instrument panel is ON.

5.10.116_APPLY software forces or bypasses to allow the pump to start including the recirc low flow. Record the forces and bypasses installed.

5.10.117__ TURN selector switch on Jet pump motor starter to ON.

5.10.118___ PRESS the pump start from DTAM.

5.10.119_ENSURE the RED light on the instrument panel is ON and the GREEN light is OFF.

5.10.120_LOWER the current input to approximately $4.8 \mathrm{~mA}$ or until Timer 4.1 starts timing on rung 0 of ladder 5 as observed on the lap top.

5.10.121_ENSURE that the amber light on the instrument panel turns ON immediately after the timer starts. 
RPP-5073

REVISION 0

5.10.122 ENSURE after a 30 second delay (Timer 4.1 times out) the following occurs:

_ "XFR Pressure LOW" alarm (alarm 1) occurs at the DTAM;

a pump shutdown occurs indicated by the hom sounding, strobe flashing; a pump shutdown alarm on the DTAM;

the red light turns $\mathrm{OFF}$; and the green light turns $\mathrm{ON}$.

ACKNOWLEDGE alarms at Data Table Access. Module to view the various alarms.

5.10.123_INCREASE the current to approximately $6 \mathrm{~mA}$ to clear the "XFR PRESSURE LOW" alarm and turn OFF amber light.

5.10.124_LEAVE the current source in place for the high pressure section.

5.10.125_RESET as necessary the forces for the high pressure test. Record changes made.

\section{HIGH PRESSURE INTERLOCK (PS-1-1) INPUT}

5.10.126__ PRESS the pump start from DTAM.

5.10.127 ENSURE the RED light on the instrument panel is ON and the GREEN light is OFF.

5.10.128_INCREASE the current to approximately $11.5 \mathrm{~mA}$ or until Timer

4.2 on rung 2 of ladder 5 starts timing as observed on the laptop computer.

5.10.129___ENSURE after a 3 second delay the following occurs:

_XFR Pressure HIGH" alarm (alarm 2) at the DTAM;

pump shutdown occurs indicated by the horn sounding, strobe flashing; shutdown alarm on the DTAM; the red light turns OFF; the green light turning $O N$.

ACKNOWLEDGE the alarms at the DTAM to view the various alarms.

5.10.130_RETURN the current to approximately $6 \mathrm{~mA}$ and leave in place for the next section. ENSURE the high pressure alarm clears.

LEAVE the software forces and bypasses in place for the next sections. 
RPP-5073

REVISION 0

5.10.132 Engineer VERIFY that section 5.10 is complete by SIGNING below.

Engineer Signature

Date

5.10.133 Quality Assurance Inspector VERIFY that section 5.10 is complete by signing below.

Quality Assurance Inspector Signature Date 
RPP-5073

REVISION 0

\subsection{DISCRETE SIGNAL INPUTS TO PLC AND DTAM}

NOTE: The DIP switches on the Intrinsic Safe Panel may require changing in order to get the proper responses for LS-1 and LS-2.

\section{JR-1 VALVE POSITION (LS-1/LS-2) INPUT}

5.11 .1 ENSURE a normally closed transducer is connected across the LS$1+$ and LS-1- and a normally open transducer across the LS-2+ AND LS2- points on the intrinsic safe terminal board in the Intrinsic Safe panel.

5.11 .2 ENSURE both transducers are actuated by a piece of steel in front of the each transducer face.

5.11.3_ENSURE the JR-1 valve indicates "norm" at the Data Table Access Module.

5.11.4_REMOVE the metal from in front of the LS-1 switch installed in the above step.

5.11.5_ENSURE the JR-1 valve indicates "NON-PROCESS" at the Data Table Access Module and address N20:32/0 is actuated on ladder 5 (rung 89).

5.11.6_ REMOVE the metal from in front of the LS-2 switch.

5.11.7_ENSURE the JR-1 valve still indicates "NON-PROCESS" at the Data Table Access Module and address N20:32/1 is actuated on ladder 5 (rung 91).

5.11 .8 REPLACE the metal in front of the LS-2 and the LS-1 transducers.

5.11.9_ENSURE the JR-1 valve indicates " norm" at the Data Table Access Module and addresses N20:32/0 and N20:32/1 are clear on ladder 5 (around rungs 89 and 91 ).

5.11.10_LEAVE the transducers in place and actuated for the following sections.

\section{DILUTION TANK NO FLOW INPUT}

5.11.11_ENSURE a normally closed switch is connected across terminal points DIL-F and CKT5H-A on terminal board TB4 in the Instrument Cabinet. 
RPP-5073

REVISION 0

5.11.12_ENSURE software forces and bypasses are in place to start the pump. Record changes made.

5.11.13_ENSURE no dilution tank no flow alarm on the DTAM (alarm 35).

5.11.14__ START the pump from the DTAM.

5.11.15__ OPEN the switch at TB4.

5.11.16 ENSURE after a 5-minute delay a dilution tank no flow alarm on the DTAM and a pump shutdown occurs.

5.11.17_ACKNOWLEDGE the alarm.

5.11.18 CLOSE the switch.

5.11.19_ENSURE alarm clears.

5.11.20_DISCONNECT the switch.

\section{FLAMMABLE GAS MONITOR INPUT}

5.11.21_ENSURE a normally closed switch is connected to points FGM and CKT5H-A on terminal board TB 4 in the instrument cabinet.

5.11.22_ENSURE software forces and bypasses are in place to start the pump. Record changes made.

5.11.23_ENSURE no FGM interlock alarm on the DTAM (alarm 22).

5.11.24_START the pump from the DTAM.

5.11.25__OPEN the switch.

5.11.26_ENSURE an FGM alarm on the DTAM and the pump shuts down immediately.

5.11.27_ACKNOWLEDGE the alarm. 
RPP-5073

REVISION 0

5.11.28_CLOSE the switch.

5.11.29_ENSURE the FGM alarm clears.

5.11.30__ LEAVE the switch connected for the Heat Trace check.

\section{HEAT TRACE CONTROL FOR PUMP AND JUMPER}

5.11.31__ ENSURE the Heat Trace control on the DTAM is OFF.

5.11.32_ENSURE that heat trace relays HT-1 and HT-2 are deenergized by checking for zero voltage across points 2 and 7 at each relay.

5.11.33_ENSURE zero voltage at TB12 between HT-1 and CKT3-N.

5.11.34_TURN ON heat trace from DTAM to actuate relays HT-1 and HT-2.

5.11.35_CHECK for 120vac at TB-12, points HT-1 and CKT3-N.

5.11.36__ OPEN the FGM switch.

5.11.37_ENSURE 0vac at TB-12, points HT-1 and CKT3-N.

5.11.38_ _ TURN OFF heat trace from the DTAM.

5.11.39_REMOVE the switch.

5.11.40__ REMOVE all software forces and bypasses.

5.11.41_ REMOVE the LS-1 and LS-2 transducers.

5.11.42 Engineer VERIFY that section 5.11 is complete by SIGNING below.

Engineer Signature $\quad$ Date

5.11.43 Quality Assurance Inspector VERIFY that section 5.11 is complete by signing below.

Quality Assurance Inspector Signature Date 
RPP-5073

REVISION 0

\subsection{HEATERS AND AIR CONDITIONER}

5.12.1 TURN the heater $\mathrm{ON}$ in the air compressor cabinet. Set the thermostat high enough to allow the unit to operate.

5.12.2 RESET the thermostat to approximately 40 degrees $F$ to allow the heat to turn OFF.

5.12.3_TURN the fan thermostat switch low to allow the fan in the air compressor cabinet to run.

5.12.4_ RESET the fan switch to approximately 90 degrees.

5.12.5 TURN the heater ON in the WFIE cabinet. Set the thermostat high enough to allow the unit to operate.

5.12.6_RESET the thermostat to approximately 40 degrees $F$ to allow the heat to turn OFF.

5.12.7_TURN the heater $\mathrm{ON}$ in the Water cabinet. Set the thermostat high enough to allow the unit to operate.

5.12.8_RESET the thermostat to approximately 40 degrees $F$ to allow the heat to turn OFF.

5.12.9_TURN the heater ON in the Instrument cabinet. Set the thermostat high enough to allow the unit to operate.

5.12.10__ RESET the thermostat to approximately 40 degrees $\mathrm{F}$ to allow the heat to turn OFF.

5.12.11_TURN ON the air conditioner in the Instrument cabinet. If necessary, remove the front grill on the unit and adjust the temperature setting lower to get the unit to operate.

5.12.12__ RESET the temperature setting to approximately 90 to 95 degrees. (Remove the grill and filter on the front of the unit for access to the adjustment.) 
RPP-5073

REVISION 0

5.12.13Engineer VERIFY that section 5.12 is complete by SIGNING below.

Engineer Signature Date

5.12.14Quality Assurance Inspector VERIFY that section 5.12 is complete by signing below.

Quality Assurance Inspector Signature Date 
RPP-5073

REVISION 0

\subsection{LEAK DETECTION INTERLOCK CHECK}

5.13.1___ Set up one or two buckets for leak detector testing if leak detector probes are used for testing.

NOTE - A supply of water needs to be available to pour into the buckets during testing.

- $\quad$ Pump operation will be simulated during the remainder of the ATP.

\section{WARNING}

Energized circuits and leads are contained inside the cabinet. Observe appropriate electrical. Comply with HNF-PRO-088, ELECTRICAL WORK SAFETY to avoid personnel electrical shock hazards.

5.13 .2

ENSURE performed the CGI dedication for the leak detector relays per HNF-4275 and WTF-1-18 and WTF-30-16.

5.13.3_ ENSURE a leak detector probe is connected to the primary leak detector terminals at TB11 in the Instrument Cabinet, points SD-1A, SD1B, SA-1A, and SA-1B and CONNECT a leak detector probe to leak detector \#1 terminals at TB11 in the Instrument Cabinet, points SD-2A, SD-2B, SA-2A, and SA-2B. IF NECESSARY remove the jumpers from the terminal block for leak detector \#1.

\section{OR}

ENSURE a normally open switch is connected to the primary leak detector terminals at TB11 in the Instrument Cabinet, points SD-1A, SD1B, SA-1A, and SA-1B and CONNECT a normally open switch to leak detector \#1 terminals at TB11 in the Instrument Cabinet, points SD-2A, SD-2B, SA-2A, and SA-2B. (NOTE: Connect SD-MA and SA-MA wires to one pole of the switch and SD-MB and SA-MB wires to the other pole of the switch.) IF NECESSARY remove the jumpers from the terminal block for leak detector \#1.

5.13.4___ENSURE no primary leak detector alarms at the DTAM (alarms 6 and 7).

5.13.5____ PLACE the primary leak detector assembly in a bucket of water or close the test switch on the primary leak detector. 
RPP-5073

REVISION 0

5.13.6_ENSURE a leak detector leak alarm for the primary leak detector is received at the DTAM (alarm 6) after a 3 second delay.

5.13 .7 ACKNOWLEDGE the Leak Detector Alarm at the Data Table Access Module.

5.13.8_REMOVE the leak detector assembly from the bucket and allow the water to drain off the assembly into the bucket or open the test switch.

5.13.9_ENSURE the leak detector alarms clear at the DTAM.

5.13.10_DISCONNECT one of the "SD" wires going to the probe or switch.

5.13.11__ ENSURE trouble alarm 7 occurs.

5.13.12_ACKNOWLEDGE the alarm.

5.13.13_ENSURE no leak detector \#1 alarms at the DTAM (alarms 18 and 19).

5.13.14___ PLACE the leak detector \#1 assembly in a bucket of water or close the switch for leak detector \#1.

5.13.15_ENSURE a leak detector leak for leak detector \#1 is received at the DTAM (alarm 18) after a 3 second delay.

5.13.16 ACKNOWLEDGE the Leak Detector Alarm at the Data Table Access Module.

5.13.17__ REMOVE the leak detector assembly from the bucket and allow the water to drain off the assembly into the bucket or open the test switch.

5.13.18__ENSURE the leak detector alarms clear at the DTAM.

5.13.19_DISCONNECT one of the "SD" wires going to the probe or switch.

5.13.20__ ENSURE trouble alarm 19 occurs.

5.13.21___ACKNOWLEDGE the alarm.

5.13.22_DISCONNECT the probes or switches from TB11.

5.13.23___ENSURE the jumpers for leak detector \#1 are installed at TB11. 
RPP-5073

REVISION 0

5.13.24 Engineer VERIFY that section 5.13 is complete by SIGNING below.

Engineer Signature Date

5.13.25 Quality Assurance Inspector VERIFY that section 5.13 is complete by signing below.

Quality Assurance Inspector Signature Date 
RPP-5073

REVISION 0

\subsection{SKID SHUTDOWN AFTER ATP}

5.14.1 Bleed the air pressure off the air system by turning the selector switch on the air compressor starter to OFF and then OPENING the air drain valves SALW-V-6043M, SALW-V-6046M, SALW-V-6047M, AND SALW-V$6037 \mathrm{M}$.

5.14.2 Ensure the following PIC skid circuit disconnects, breakers and fuses are OPEN or OFF.

\begin{tabular}{ll} 
SALW-DS-6002M & SALW-DS-6003M _ _ SALW-DS-6005M \\
\hline DS-6004M & SALW-
\end{tabular}

The following breakers are in distribution panel SALW-DP-6001M:

\begin{tabular}{l} 
Breaker "MAIN" \\
Breaker 1 \\
Breaker 3 \\
Breaker 5 \\
Breaker 7 \\
Breaker 9 \\
\hline Breaker 11 \\
\hline Breaker 13
\end{tabular}

Breaker 2
Breaker 4
Breaker 6
Breaker 8
Breaker 10
Breaker 12
Breaker 14

5.14.3_ DISCONNECT the power plug from the 480vac power source.

5.14.4 Ensure the following PIC skid valves in the WFIE cabinet are OPEN. SALW-V-6035M (EQUALIZING) SALW-V-6036M (EQUALIZING)

5.14.5 Ensure the following PIC skid valves are CLOSED.

Air Compressor cabinet:

SALW-V-6025M

SALW-V-6026M

SALW-V-6034M

SALW-V-6043M

SALW-V-6044M

SALW-V-6046M

SALW-V-6047M

SALW-V-6048M

SALW-V-6049M
Water cabinet:

SALW-V-6027M

SALW-V-6028M

SALW-V-6029M

SALW-V-6030M

SALW-V-6031M

SALW-V-6032M

SALW-V-6037M 
RPP-5073

REVISION 0

WFIE Cabinet:

SALW-V-6001M

SALW-V-6002M

SALW-V-6003M

SALW-V-6004M

SALW-V-6005M

SALW-V-6006M

SALW-V-6007M

SALW-V-6008M

SALW-V-6011M

SALW-V-6012M

SALW-V-6013M

SALW-V-6014M
SALW-V-6015M

SALW-V-6016M

SALW-V-6017M

SALW-V-6018M

SALW-V-6019M

SALW-V-6020M

SALW-V-6021M

SALW-V-6035M LOW

SALW-V-6035M HIGH

SALW-V-6036M LOW

SALW-V-6036M HIGH

5.14 .6

ENSURE the power plug on the power cable is the correct model per H-14-103546, item 41.

5.14.7 Engineer VERIFY that section 5.14 is complete by SIGNING below.

Engineer Signature

Date

5.14.8 Quality Assurance Inspector VERIFY that section 5.14 is complete by signing below.

Quality Assurance Inspector Signature Date 
RPP-5073

REVISION 0

\subsection{REDLINE INCORPORATION}

5.15.1_ENSURE the redlines identified in the redline log in the Fabrication work package are incorporated into the revised drawings for skid " $\mathrm{M}$ ".

NOTE: Redlines incorporation must meet the intent of the redline log. The redlines may not be exactly the same as marked on the working drawings. Example: If a part was added to a drawing and then it is discovered that the part already existed on the drawing, then the final incorporation may be to increase the quantity of the existing part. Drawing views may change from the redline version in order to meet drafting standards.

5.15.2 Engineer to VERIFY section 5.15 is completed by signing below.

\begin{tabular}{ll}
\hline Engineer Signature & Date
\end{tabular}

5.15.3 Quality Assurance Inspector to VERIFY section 5.15 is completed by signing below.

Quality Assurance Inspector Signature

Date 


\section{RPP-5073 \\ REVISION 0 \\ ACCEPTANCE TEST PROCEDURE}

This page may be reproduced as necessary

PAGE of

\begin{tabular}{|c|c|c|}
\hline \multicolumn{3}{|c|}{ ACCEPTANCE TEST PROCEDURE LOG } \\
\hline Name & Date & Comment \\
\hline & & \\
\hline & & \\
\hline & & \\
\hline & & \\
\hline & & \\
\hline & & \\
\hline & & \\
\hline & & \\
\hline & & \\
\hline & & \\
\hline & & \\
\hline & & \\
\hline & & \\
\hline & & \\
\hline
\end{tabular}


RPP-5073

REVISION 0

\section{ACCEPTANCE TEST PROCEDURE EXCEPTION LOG}

This page may be reproduced as necessary

PAGE of

ACCEPTANCE TEST PROCEDURE EXCEPTION LOG

\begin{tabular}{|c|c|c|}
\hline Number & Date & Description \\
\hline & & \\
\hline & & \\
\hline & & \\
\hline & & \\
\hline & & \\
\hline & & \\
\hline & & \\
\hline & & \\
\hline & & \\
\hline & & \\
\hline & & \\
\hline & & \\
\hline & & \\
\hline & & \\
\hline & & \\
\hline & & \\
\hline
\end{tabular}


RPP-5073

REVISION 0

\section{ACCEPTANCE TEST PROCEDURE EXCEPTION RECORD}

This page may be reproduced as necessary.

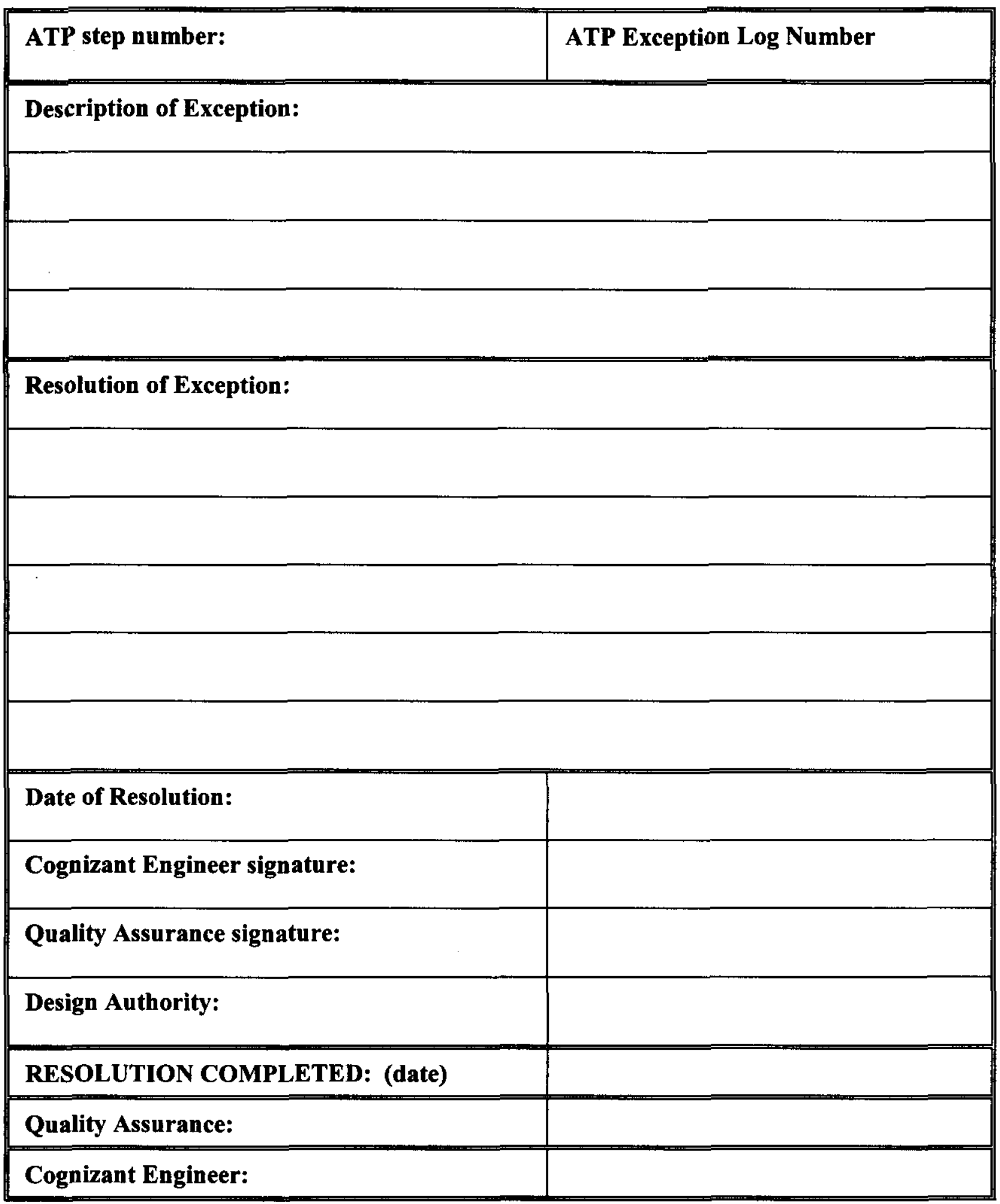


RPP-5073

REVISION 0

\section{ACCEPTANCE TEST PROCEDURE ACCEPTANCE RECORD}

This Acceptance Test Procedure has been completed and the results, including red-line changes, exceptions, and exception resolutions, have been reviewed for compliance with the intent of the Purpose (Section 1.0). The test results are accepted by the undersigned:

Cognizant Engineer (Signature)

(Print Name)

Date

Quality Assurance (Signature)

(Print Name)

Date 


\section{RPP-5073 \\ REVISION 0 \\ PROCEDURE PERFORMER SIGNATURE SHEET}

All personnel who will be performing, initialing and signing the procedure shall enter their printed name, signature and initials below.

\begin{tabular}{|c|c|c|}
\hline PRINT NAME & SIGNATURE & INITIALS \\
\hline & & \\
\hline & & \\
\hline & & \\
\hline & & \\
\hline & & \\
\hline & & \\
\hline & & \\
\hline & & \\
\hline & & \\
\hline & & \\
\hline & & \\
\hline & & \\
\hline & & \\
\hline & & \\
\hline & & \\
\hline & & \\
\hline & & \\
\hline & & \\
\hline & & \\
\hline
\end{tabular}


RPP-5073

REVISION 0

\section{PRE-JOB BRIEF SIGNATURE PAGE}

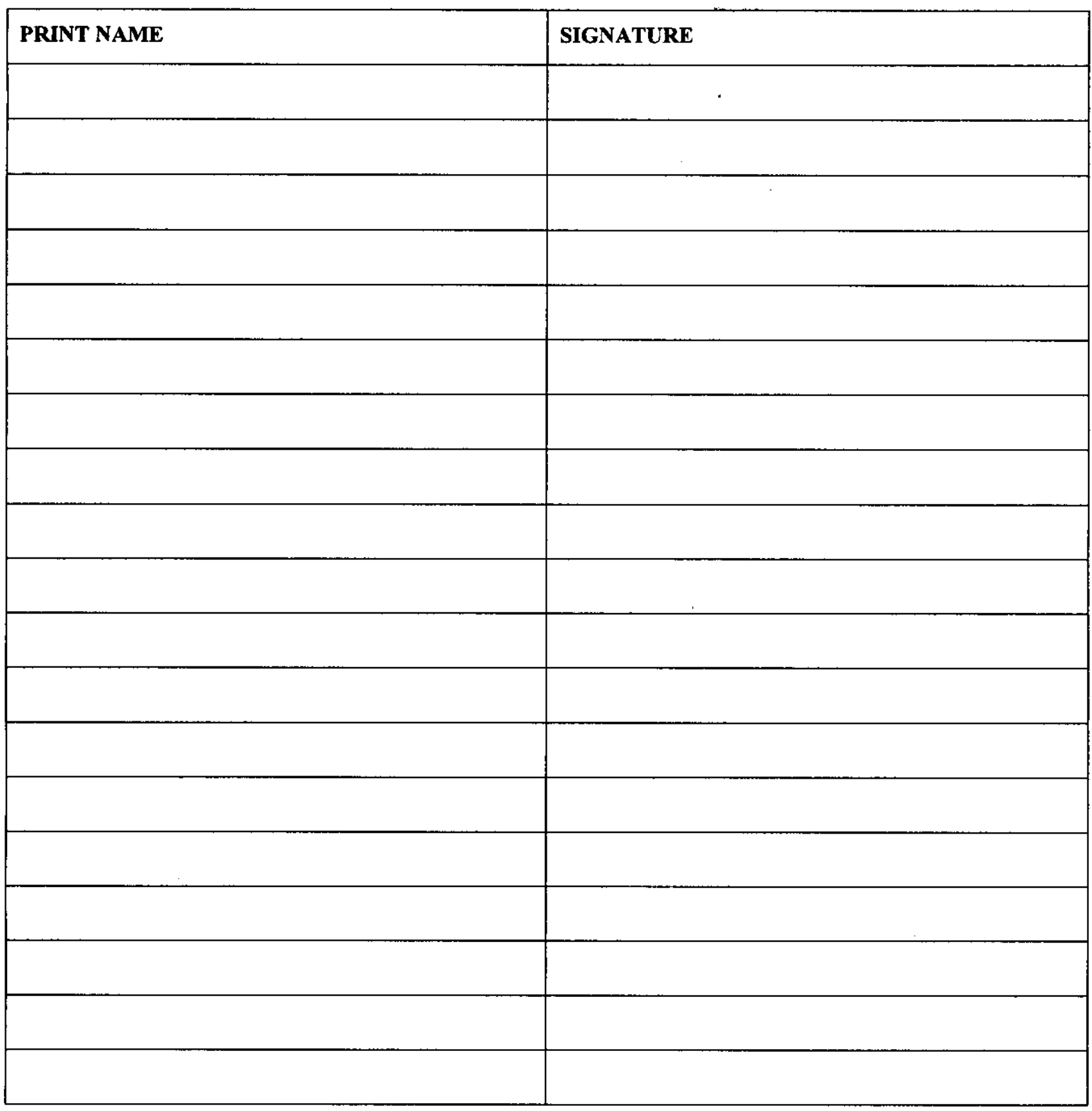

